This is an electronic reprint of the original article. This reprint may differ from the original in pagination and typographic detail.

Author(s): Koskinen, Satu; Lämsä, Anna-Maija

Title: $\quad$ The CEO-Chair relationship from a relational leadership perspective

Year: $\quad 2016$

Version:

Please cite the original version:

Koskinen, S., \& Lämsä, A.-M. (2016). The CEO-Chair relationship from a relational leadership perspective. Leadership and Organization Development Journal, 37(8), 1135-1146. https://doi.org/10.1108/LODJ-07-2015-0158

All material supplied via JYX is protected by copyright and other intellectual property rights, and duplication or sale of all or part of any of the repository collections is not permitted, except that material may be duplicated by you for your research use or educational purposes in electronic or print form. You must obtain permission for any other use. Electronic or print copies may not be offered, whether for sale or otherwise to anyone who is not an authorised user. 


\title{
The CEO-Chair relationship from a relational leadership perspective
}

To cite this article:

Koskinen, Satu \& Lämsä, Anna-Maija (2016). The CEO-Chair relationship from a relational leadership perspective. Leadership \& Organization Development Journal 37(8), $1135-1146$.

\begin{abstract}
Purpose - The purpose of this study is to conceptualise how the CEO and Chair construct their relationship through their leadership practices, and to analyse the meaning of these practices to the relationship. An empirical investigation from both partners' viewpoint is conducted.

Design/methodology/approach - The data were gathered through in-depth interviews with 16 CEOs and 16 Chairpersons from the same companies. Content analysis was used to analyse the data.

Findings - Four types of leadership practices in the CEO-Chair relationship were conceptualised: emergent practices on company-related and person-related issues, and scheduled practices on company-related and person-related issues. For the effectiveness of the relationship, emergent practices on company-related issues seem to be most important.
\end{abstract}

Research limitations/implications - The basing of the analysis on interviewees' descriptions rather than on the observation of leadership practices in action can be considered a limitation.

Practical implications - Knowledge of leadership practices in the CEO-Chair relationship and their meaning to the relationship can be utilised in leadership training.

Originality/value - This research contributes to the relational leadership literature by highlighting a specific leadership relationship, the CEO-Chair relationship, from both partners' viewpoint. Additionally, the value of the study is that it shows that the CEOChair relationship is more multifaceted than traditionally assumed in prior literature. 
Key words Chief Executive Officer (CEO), Chairperson of the Board (Chair), Relational leadership, Leadership practices, Qualitative research

Paper type Research paper 


\section{Introduction}

This study examines the relationship between the Chief Executive Officer (CEO) and Chairperson of the Board (Chair) from the perspective of relational leadership. Despite some examples (e.g. Chitayat, 1985; Stewart, 1991; Roberts and Stiles, 1999; Kakabadse et al., 2006; Kakabadse et al., 2010), research focusing on the CEO-Chair relationship in general, and specifically from both partners' viewpoint, which is in focus here, has been rare. However, the CEO-Chair relationship has been argued to be pivotal to the performance of a company's Board of Directors as well as necessary for effective governance (Kakabadse et al., 2006). A strong CEO-Chair relationship is at the heart of a complementary Board and necessary to the Board's effectiveness (Roberts, 2002). The relationship has been noted to provide a powerful position to set the leadership tone for the whole Board, and the way the relationship is practised sends signals to the wider organisation (Roberts and Stiles, 1999). The CEO-Chair relationship has been described as special, even mystic, and it has been suggested that the chemistry between the partners is an influential element in the relationship (Kakabadse et al., 2010).

Some reasons for the limited number and scope of studies on the CEO-Chair relationship can be identified. The dominant US governance model of CEO duality, i.e. the practice of a single individual serving as both CEO and Chairperson of the Board, is a major reason. Gabrielsson and Huse (2004) argue that the majority of empirical studies on Board work view the actual practices of the Board as a black box, and it is assumed that the conduct and behaviour of Board members can be concluded from the Board's demographic characteristics. One reason may be that getting access to these managerial elites (Pettigrew, 1992) can be difficult.

The CEO-Board relationship has primarily been investigated from the viewpoint of agency theory (Boyd et al., 2011). However, the dominant agency theory gives a far too limited view of the CEO-Chair relationship. The application of agency theory (Jensen and Meckling, 1976) results in the idea that the dyadic parties have conflicting objectives and lack mutual trust: the CEO is seen as an economic agent motivated by high rewards 
and therefore the Chair must apply high levels of control. Agency theory neither acknowledges that the roles and tasks of CEO and Chair are interlinked in many ways (Stewart, 1991; Roberts and Stiles, 1999; Roberts, 2002), nor takes into consideration that the CEO can be motivated by factors other than economic rewards, such as challenging work, the achievement of results and a feeling of self-fulfilment (Kulla, 2011).

It is argued in this study that the CEO-Chair relationship is not only an economic exchange relationship, as suggested in agency theory (Jensen and Meckling, 1976) or an arrangement to mediate against abuse of the leadership position (Kakabadse et al., 2007), but is more multifaceted. Therefore, an empirical study was conducted with the objective of making visible and conceptualising how the CEO-Chair relationship is constructed through leadership practices. In particular, the following research questions are answered: What kind of leadership practices are described by the CEO and the Chair as significant to their relationship? What is the meaning of the leadership practices to the relationship?

This study makes a contribution to relational leadership literature by studying the construction of this specific leadership relationship from the viewpoint of both partners. Despite increasing interest in leadership relationships (Uhl-Bien, 2006), leadership researchers have primarily viewed leadership as a leader-centred phenomenon focusing on an individual leader's traits and behaviour (Wood, 2005; Carroll et al., 2008). In line with a suggestion of Crevani et al. (2010) and Uhl-Bien and Ospina (2012), the stance taken in this paper attempts to challenge a general assumption in leadership research that the objects of study - leaders and followers - are independent from each other. Instead, leadership is seen as constructed through people's practices and interactions, specifically in this study, of the Chair and the CEO.

\section{Theoretical framework}

\section{Characteristics of the CEO-Chair relationship}


The CEO-Chair relationship has peculiar features not found in a typical leadership relationship between a leader and an employee. Firstly, it is the duty of the Board of Directors as a collective to supervise the CEO, but the person-to-person tasks of the leader are normally conducted by the Chair. This is a major difference from a typical leader-employee relationship, where an employee would in most cases have only one person as her/his superior, and a superior would normally have several employees, rather than vice versa.

Secondly, the tasks of the Board have been argued to simultaneously include three different and even contradictory elements: control, service and strategy (Zahra and Pearce, 1989). These different tasks can have a significant influence on the role and work of the Chair as well as her/his relationship with the CEO, because there is an inherent conflict in performing them: the control task would be enhanced by the independence of the non-executive directors, such as the Chair, whereas the task of service implies an intimate relationship with the management (e.g. Zhang, 2013).

Thirdly, the typically non-executive, part-time position of the Chair results in an information asymmetry with the $\mathrm{CEO}$, who has more company-specific information than the Chair (and, in fact, than the whole Board) (e.g. Hooghiemstra and Van Manen, 2004; Zhang, 2013). Finally, there is a considerable amount of independence, freedom and responsibility attached to the position of CEO, even though previous research (e.g. Stewart, 1991; Roberts and Stiles, 1999; Roberts, 2002) has proposed a strong interdependency and complementarity between CEO and Chair.

\section{CEO-Chair relationship and leadership practices}

This study draws upon relational leadership theory, which assumes that the CEO-Chair relationship is created by the partners through social practices, rather than through the actions of individual leaders (Uhl-Bien, 2006; Carroll et al., 2008; Crevani et al., 2010; Tourish and Barge, 2010; Raelin, 2011; Uhl-Bien and Ospina, 2012). In this study the construction of the CEO-Chair relationship is investigated through leadership practices: 
how the CEO and Chair do leadership in their dyadic relationship (cf. Whittington, 1996; Denis et al., 2010). The practice turn in leadership studies emphasises relationalism, interaction and the primacy of relations over the individual or organisation, and tries to get closer to the mundane, everyday activities of the practices in the relationship (Chia and Holt, 2006).

According to Crevani et al. (2010), leadership can be conceptualised through the notions of direction, co-orientation and action space, as they are constructed in the practices of organisational interaction. Lindgren and Packendorff (2011) applied this conceptualisation to a study of distributed leadership in a project leadership setting and concluded that leadership practices in that context evolved around the continuous construction of issues, responsibilities and identities. They recognised the importance of the ongoing processing of ambiguities, rather than formal decision making, to take the project forward.

Direction refers to leadership interaction that constructs organisational paths, overall goals and mission of an organisation (Crevani et al., 2010). In general, direction is an essential element in many definitions of leadership; most definitions include a social influence process aimed at facilitating the achievement of common objectives (Yukl, 2006). Some scholars, such as Drath et al. (2008 p. 636), conceptualise direction as one of the key outcomes of leadership, defining it as 'widespread agreement in a collective on overall goals, aims and mission'. The notion of direction as the construction of organisational paths, overall goals and mission relates to the construction of organisational strategy, in which the creation of strategy is understood as a socially accomplished activity, constructed through the actions and negotiations and situated practices of the partners (cf. Jarzabkowski et al., 2007). Direction highlights the strategic nature of the CEO-Chair relationship.

The conceptualisation of co-orientation as enhanced understandings of the possibly diverging arguments, interpretations and decisions of all involved parties (Crevani et al., 2010) importantly includes the possibility of not agreeing and finding a common view 
(i.e. one direction) on all issues. Diverging opinions are not seen as dysfunctional leadership per se, but rather a normal part of organisational life and leadership relationships. An emerging sense that divergences are not understood or recognised is dysfunctional from the perspective of leadership, and can result in value conflicts and reduced mutual understanding (Lindgren et al., 2011).

The third concept in the analysis of the construction of the leadership relationship is action space (Crevani et al., 2010). This concerns the construction of possibilities, opportunities and limitations for individual and collective action within the organisational context. Rather than examining how the leader influences or limits the space of action of followers, action space is understood to be co-constructed in interaction. Leadership is largely dependent on the constellation of co-leaders with complementary roles (Denis et al., 2010).

It has been proposed that the ability of the CEO and Chair to interpret events and information 'in a mutually synergistic manner' is critical for strong ties and a successful relationship (Kakabadse et al., 2006). According to a study by Holmberg and Tyrstrup (2010), interpretative processes in which leadership partners attempt to understand what has happened (or has not happened, even if it was expected) are a significant part of leadership practices. In the flow of events, there is a constant need for new interpretations of upcoming situations, followed by new adjustments, choices and temporary solutions. An interpretation that points in a certain direction has to be made first. After the interpretation, decisions concerning adjustments or choices and solutions can be made. Holmberg and Tyrstrup (2010) propose that leadership is event-driven rather than intention-driven, largely dealing with unforeseen or unplanned events. In a similar vein, Chia and Holt (2006) argue that strategy emerges through practical coping and relational dwelling, rather than being a result of actors as distinct entities conducting purposeful strategic activities.

\section{Method}


A qualitative research strategy was applied, with open-ended in-depth interviews conducted individually with each dyadic partner. An open-ended interview means here that the interview is open in two ways (Eriksson and Kovalainen, 2008): there were no prior hypotheses to be tested, and the interviewees were encouraged to openly describe their experiences of the topic. Studying the relationship from the viewpoint of both dyadic partners, rather than only one, is in line with the understanding of leadership as a relational phenomenon.

The interview material comprises 16 interviews with CEOs and 16 interviews with Chairpersons from the same listed and non-listed Finnish limited companies. The Finnish Companies Act allows the combined role of CEO and Chair (CEO duality), but separation of the roles complies with the Finnish Corporate Governance Code (Arvopaperimarkkinayhdistys ry, 2010), which justifies the need to separate the roles with the Board's duty to supervise and control the CEO. Moreover, the Code recommends that the majority of Board members shall be independent, non-executive directors, i.e. not have an employment relationship or service contract with the company. However, these restrictions do not apply to non-listed companies.

Purposeful sampling (Eriksson and Kovalainen, 2008) was used to select a variety of information-rich cases for the interviews. The aim was to pick dyads that were different from each other in regard to some of the factors that might, based on previous studies of Board work and corporate governance (see Huse, 2005), influence the CEO-Chair relationship. The primary criteria used included ownership type, the size of the company in terms of employees, and the length of the relationship. Additionally, a number of different criteria, such as gender, personal ownership of the CEO and the Chair in the company, company life cycle, financial performance and ownership concentration, were considered in the sampling to ensure a diverse sample. Based on these criteria, 16 dyads agreed to join in the study. The problem of access difficulties (Pettigrew, 1992) in studying managerial elites did not occur in this study. 
The sampling resulted in a group of 31 dyadic interview participants and 32 interviews, as one person participated as the CEO of one company and the Chair of another. Two CEOs and two Chairpersons were female, and all the others were male. In one dyad, both partners were female. No data are available about the gender composition of CEOs and Chairpersons in all Finnish companies. However, a survey conducted in 2013 in large companies shows that only a very small minority of CEOs and Chairpersons (from 0.8 to 9 percent depending on the company type) are women (Pietiläinen et al., 2015). The length of the relationship was 1-2 years for five dyads, 2-5 years for four dyads and more than five years for seven dyads. Two Chairpersons, both also major owners in the company, worked for the company full-time, and one Chair had a fixed-amount part-time agreement. None of the other Chairpersons had an agreed, fixed amount of work time to be used in the role.

Each interview typically lasted approximately 90 minutes. The interviews were audiorecorded and transcribed word for word. The materials were first read through several times and then coded using software for qualitative data analysis, Atlas.ti, to extract the sentences and phrases in which practices of the CEO-Chair relationship were described. A content analysis (Krippendorff, 2013) of these extracts was conducted and the material was arranged into categories, which were formed and re-formed based on the data during the analysis. The analysis process was iterative and guided by the theoretical framework of the study, with the empirical data and the theoretical literature continuously linked together in the analysis.

\section{Results}

The interviewees described both emergent practices and scheduled practices. As regards the themes of the practices, considerable emphasis was laid on company-related issues, but person-related issues were also mentioned as being addressed in the relationship. Based on the dimensions of the scheduling and theme of practice, four forms of dyadic practices were conceptualised: emergent practices on company-related issues, emergent practices on person-related issues, scheduled practices on company-related issues, and 
scheduled practices on person-related issues. Two dyads reported all four forms, six dyads three forms, and eight dyads two forms of these practices. A summary of the results is presented in Figure 1.

Emergent practices
Scheduled practices

\section{Emergent company-related issues}

Main initiation: CEO

Typical practices: Phone calls, emails and meetings about emerging, unexpected events to interpret the meaning of the events and consider possible responses

Meaning to the relationship:

Builds and maintains co-orientation, direction and trust

Scheduled company-related issues

Main initiation: Chair

Typical practices: Meetings, phone calls, e-mails about preparation for Board meetings or strategic plans Meaning to the relationship: Enhances predictability concerning issues presented in the Board meeting and the other partner's views on those issues

\section{Emergent person-related issues}

Main initiation: Either of the partners Typical practices: Informal face-toface discussions on work-life balance or personal crises

Meaning to the relationship:

Enhances the emotional bond, mutual understanding and feeling of support between the partners

\section{Scheduled person-related issues}

Main initiation: Chair

Typical practices: Performance and/or development discussions on the CEO's objectives and performance Meaning to the relationship: Enhances congruency on CEOs performance, development needs and remuneration, and increases certainty and co-operation in the relationship
Company-

related issues
Person-related issues

Figure 1. The types of leadership practises in the CEO-Chair relationship 
The most frequent leadership practices between the partners were said to concern company-related, emerging issues such as problems, opportunities and other unexpected events, and to occur rather often, that is from once or twice a month to several times a week. 15 dyads reported these practices, which were said to be largely CEO-initiated. Information asymmetry was cited as a major reason for these: the CEO is normally aware of emerging issues before the Chair, who does not participate in the company's daily routines. The respondents emphasised that 'no surprises' is an important principle in the relationship and also a prerequisite for mutual trust. In order not to cause the Chair any surprises, CEOs said that they immediately reported emerging issues and discussed major plans with the Chair as early as possible, i.e. well before they were ready to be presented to the Board. One CEO explained the role of early information as follows: 'Because if I don't discuss these kinds of big projects with the Chair right at the start, I'm hiding them. And then, our co-operation does not develop well.'

The CEO also needed to trust the Chair not to use information she/he got from the CEO about emerging challenges to limit the CEO's action space, as some CEOs put it, 'interfere in the details', 'do any trick that would interfere' or 'misuse the information'. The CEOs emphasised that in most cases their intention in informing the Chair about an issue was not that the Chair would make a decision or take charge: it was considered inappropriate for the Chair to try to use any power over the CEO in such a case.

Co-orientation and direction in the relationship were said to be maintained and developed by sharing interpretations on the meaning of emerging company challenges and opportunities, and by discussing possible responses to them. One Chair underlined the importance of continuous information sharing and discussion between the Chair and CEO so that they were prepared when an actual issue emerged: 'We must discuss things so that we are prepared to make decisions when all of a sudden the situation demands it.'

The meaning of these, often CEO-initiated, practices was to build mutual trust between the CEO and the Chair. In general, emergent practices on company-related issues were described as being more about making interpretations and influencing each other than 
about making decisions, as the decision-making authority in many of these issues lies with the Board as a whole. Finally, it is worth mentioning that overall company strategy was said to form boundaries to the partners' space for action. Moreover, Chairpersons said that they aimed to focus their action on strategic rather than operational issues.

\section{Emergent practices on person-related issues}

Five dyads talked about emergent practices on person-related issues, i.e. not dealing with company-related topics but concerned with the personal well-being of one or other of the partners, mostly the CEO. These practices, which were initiated by either of the partners, occurred quite seldom. Due to the personal nature of these issues, they were mostly discussed in informal face-to-face discussions. For example, four dyads said that they had addressed issues concerning work-life balance and well-being. Additionally, sharing experiences and talking about feelings in difficult situations, such as personnel conflicts, dismissing staff or a divorce or death in the family, were mentioned. It was felt that a more informal and open relationship enhanced mutual understanding, promoted coorientation in the relationship and deepened mutual trust; it helped the partners find appropriate solutions to and to cope with challenging personal situations that also contributed to achieving direction in the relationship.

One reason why the partners thought that it was important to know about major personrelated issues was that such issues can have an effect on either partners' possibilities of fulfilling their responsibilities. Particularly, the respondents were of the opinion that the Chair needs to know about major challenges and problems in the personal life of the CEO as these may affect the latter's work performance. However, the creation and maintenance of professional proximity, not close friendship, was regarded by interviewees as an important condition for an effective relationship. The distinction was described by one CEO in the following way: 'I can't imagine being a good friend or even family friends with the Chair. That would begin to make, it would make things difficult for the working relationship. ' In particular, the possible need to sack the CEO was raised by one Chair as a reason why the Chair should not form a too close personal relationship 
with the CEO: '...and then, if you're family friends, you do not sack someone who's a friend of the family.'

For the respondents, the meaning of being aware of each other's major personal issues was to enhance the emotional bond between the partners, but not too closely, in terms of mutual understanding and a feeling of support. Even though professional proximity was mainly thought to be important for work reasons, the interviewees admitted that proximity was also important for making them feel that they have a rewarding and satisfactory relationship with each other.

\section{Scheduled practices on company-related issues}

Scheduled practices on company-related issues were said to mainly occur according to a pattern initiated by the Chair, even if the issues and materials discussed in these practices were mostly prepared by the CEO. Advance preparation for Board meetings was the most important scheduled practice, and all but one dyad said they agreed on the agenda of the Board meeting beforehand. The usual frequency of these practices was 5-12 times in a year (depending on the frequency of Board meetings), and the issues were said to be discussed either in scheduled meetings, or by phone or e-mail. Additionally, ten dyads mentioned that they had regular, more thorough face-to-face discussions on strategic issues a couple of times a year in order to maintain and develop co-orientation and direction in their relationship.

Company-related, scheduled practices gave the Chair vital information for planning and chairing Board meetings, and made it possible for her/him to ensure that the Board received enough good-quality information and well-prepared proposals to manage its tasks. For the CEO, these practices provided an opportunity to prepare the Chair for decisions to be made in future Board meetings, test out proposals, and seek and possibly secure the Chair's support for them. 
Within three dyads, the joint preparation for Board meetings was said to be limited to checking over the CEO's suggestion for the agenda. However, the vast majority, i.e. 12 dyads, said that they would also discuss at least the most important issues on the agenda, particularly proposed decisions. The respondents expressed the need for discussion when there was any ambiguity or divergence in direction on any major company issues and emphasised the importance of finding a common view on direction.

The need to achieve convergence before the meeting and avoid surprises between the partners in the Board meeting is highlighted in the following comment by a Chair: ' $O f$ course, the meeting we have before Board meetings is formal. Also, there might be some sort of new type of, if there's some company buy-out type of thing, then we might meet many times to discuss it. With the idea that then when it comes before the Board we are in agreement.' The respondents of only two dyads said that sometimes they would knowingly take a proposal they disagreed about to a Board meeting to see which view won; ten dyads said that such behaviour would be inappropriate or at least highly unlikely, and that they therefore discussed any issue between the partners long enough to find a shared view before a proposal was presented to the Board - if it was presented to the Board at all.

For both the CEO and the Chair, the meaning of the scheduled practices on companyrelated issues was to reduce uncertainty. Their goal with these practices was to increase predictability in the relationship: they functioned above all as a controlling mechanism to prevent unforeseen and unpleasantly conflicting views emerging in Board meetings.

\section{Scheduled practices on person-related issues}

As regards scheduled practices on person-related issues, seven dyads reported that they conducted a scheduled discussion to evaluate development and/or performance once or twice a year. The interviewees said that this was usually initiated by the Chair and was a face-to-face meeting, since it could concern sensitive, personal issues. 
The respondents reported that these practices included discussions on performance, objectives, remuneration and the development needs of the CEO, as well as mutual feedback concerning the relationship. One Chair described them as follows: 'Then once a year there's a perfectly normal performance appraisal meeting to discuss how things are going, when we talk about goals for the coming period, bonuses, all that sort of thing. Then at the end of the year we go through these things, let's say, how well we're doing, and all that. But then also perhaps more broadly about how well we've been working together and what hopes we have. And we write it all down on paper.' The scheduled practices on person-related issues were described as focusing on the CEO's work and performance in her/his current position. Through these practices the partners aimed to find and define guidelines to give appropriate action space, particularly to the CEO.

In sum, the partners aimed for congruency in scheduled practices on person-related issues, mostly concerning discussions of the CEO's performance, development needs and her/his remuneration. The meaning of the scheduled practices on person-related issues was to increase the respondents' certainty and co-operation in their relationship; these practices functioned as a mechanism that controlled possible relational risks in CEOChair co-operation.

\section{Discussion}

In this study, four groups of leadership practices were found to be significant in the CEOChair relationship. However, in line with Lindgren and Packendorff (2011) it can be said that these practices are not isolated entities, but dynamically influence each other. The results confirm the suggestion of Crevani et al. (2010) and Lindgren and Packendorff (2011) that a leadership relationship, such as the CEO-Chair relationship in this study, is dynamic by nature and evolves around continuous processes of construction between the partners. This research suggests that the main dynamic in the practices of the CEO and the Chair emerges out of the interplay between trust and control. Mutual trust can be constructed particularly through emergent practices. Control occurs in scheduled 
practices to manage performance and relational risks in the relationship, and also in relation to the Board.

The results indicate that particularly emergent practices on company-related issues operate as the 'engine' of an effective relationship between the partners. Consequently, it is suggested that emergent practices on company-related issues - usually initiated by the CEO, the dominant information-holder in the relationship (Hooghiemstra and Van Manen, 2004) - are an important basis for an effective CEO-Chair relationship. These practices, as they relate to company issues, can offer a smooth and natural way to build a trusting relationship between the two. As regards the suggestion by Zahra and Pearce (1989) of a Board's diverse roles, the findings of this research suggest that rather than control, tasks related to strategy and service seem to be meaningful to the functioning of the CEO-Chair relationship. Still, the results highlight that scheduled, company-related practices are significant for defining direction in the relationship as well as overall company strategy, as the Board's decisions are based on the agenda determined in these practices. In sum, emergent practices appear to be more meaningful to service tasks while scheduled practices are related to the Board's control tasks. The task of strategy is enhanced in both emergent and scheduled practices, and particularly in company-related practices.

This study suggests that mutual trust, which allows the partners to rely on each other's intentions and behaviour, is pivotal to co-orientation, direction and action space (Crevani et al., 2010) in the CEO-Chair relationship. Therefore, it is proposed that in the future it is important to investigate further the forms and occurrence of trust in the relationship. Additionally, since trust is fragile, loss of trust in the relationship merits research.

The findings show that the CEO-Chair relationship involves an emotional bond that is related to the dynamics of proximity and distance. Proximity could provide support and mutual understanding, the latter of which contributed to co-orientation in the relationship in particular. However, some conscious distancing, called professional proximity in this study, was considered appropriate by the partners to keep the relationship functioning and 
reliable. All in all, this research brings out the emotional element in leadership relationships such as the Chair-CEO relationship.

An important practical implication of this study that can be utilised in developing the CEO-Chair relationship is the increased knowledge and visibility it gives of the different forms of practices and their meaning in the relationship, particularly in the development of trust. It is suggested that especially new CEOs and Chairpersons could benefit from training and coaching in the practices and dynamics of their relationship. At least the importance of joint, open discussion about the partners' expectations of relational practices needs to be highlighted.

The limitations of this research must be kept in mind. One is that the analysis is based on interviewees' descriptions rather than observed leadership practices as they occur in action. However, the empirical data can be considered valuable due to the interview access to 16 dyads rather than only to one or other partner. Nevertheless, because of the confidentiality promised to respondents as regards the comments of their dyadic partner, the comments are not presented here in a dyadic setting. The study is also limited to Finnish companies; studying the topic in other contexts would be valuable. Finally, this study focused only on the dyadic relationship between the CEO and the Chair. Investigating the influence of the Board on the relationship and vice versa would be fruitful.

\section{Conclusion}

Based on the findings of this study it can be concluded that the CEO-Chair relationship is dynamic (Crevani et al., 2010; Lindgren and Packendorff, 2011) and is formed through multiple leadership practices (Chia and Holt, 2006; Carroll et al., 2008; Raelin, 2011). In this study the leadership practices that guide co-orientation, direction and action space (Crevani et al., 2010) in the CEO-Chair relationship were conceptualised into four groups: emergent practices on company-related and person-related issues, and scheduled practices on company-related and person-related issues. The practices tended to be 
mostly event-driven, especially emergent practices, but also intention-driven, specifically scheduled practices. Consequently, it is argued that not only event-driven practices, as proposed by Holmberg and Tyrstrup (2010), are important to an effective leadership relationship, but intention-driven practices are also needed.

The application of agency theory (Jensen and Meckling, 1976) has been dominant in prior research on relations between CEO and Board members (Boyd et al., 2011). This research shows that the application of the approach can be criticised for two main reasons. First, in line with the suggestion of Roberts and Stiles (1999) and Roberts (2002), it can be said that the CEO-Chair relationship is interlinked in many ways. This is a perspective that has not been taken seriously in research drawing upon agency theory (Jensen and Meckling, 1976). Second, agency theory emphasises the economic nature of the relationship. However, from this study it can be concluded that the CEO-Chair relationship is more multifaceted, and specifically co-orientation, a common view on company direction, mutual trust and emotional binding are meaningful elements in the relationship. Finally, CEO-initiated emergent practices seem to be crucial to the development of these elements in the relationship. It can therefore be said that even though the Chair represents the formal leader, i.e. the Board, in the relationship, in practice the influence of the CEO seems to be stronger in this respect.

\section{References}

Arvopaperimarkkinayhdistys ry (2010),’Suomen listayhtiöiden hallinnointikoodi (Corporate Governance)", available at: http://cgfinland.fi/files/2012/01/suomenlistayhtioidenhallinnointikoodi-cg2010.pdf (accessed 17 December 2012).

Boyd, B.K., Haynes, K.T. and Zona, F. (2011), "Dimensions of CEO-Board relations", Journal of Management Studies, Vol. 48 No. 8, pp. 1892-1923.

Carroll, B., Levy, L. and Richmond, D. (2008), "Leadership as practice: challenging the competency paradigm” Leadership, Vol. 4 No. 4, pp. 363-379.

Chia, R. and Holt, R. (2006), "Strategy as practical coping: A Heideggerian perspective", Organization Studies, Vol. 27 No. 5, pp. 635-655. 
Chitayat, G. (1985), "Working relationships between the chairman of the Boards of directors and the CEO", Management International Review, Vol. 25 No.3, pp. 65-70.

Crevani, L., Lindgren, M. and Packendorff, J. (2010), "Leadership, not leaders: On the study of leadership as practices and interactions", Scandinavian Journal of Management, Vol. 26 No. 1, pp. 77-86.

Denis, J.L., Langley, A. and Rouleau, L. (2010), "The practice of leadership in the messy world of organizations", Leadership, Vol. 6 No. 1, pp. 67-88.

Drath, W.H., McCauley, C.D., Palus, C.J., Van Velsor, E., O'Connor, P.M. and McGuire, J.B. (2008), "Direction, alignment, commitment: Toward a more integrative ontology of leadership", The Leadership Quarterly, Vol. 19 No. 6, pp. 635-653.

Eriksson, P. and Kovalainen, A. (2008), Qualitative Methods in Business Research, SAGE, London.

Gabrielsson, J. and Huse, M. (2004), "Context, behavior, and evolution: Challenges in research on Boards and governance", International Studies of Management \& Organization, Vol. 34 No. 2, pp. 11-36.

Hooghiemstra, R.B.H. and Van Manen, J.A. (2004), "The independence paradox: (im)possibilities facing non-executive directors in the Netherlands", Corporate Governance: An International Review, Vol. 12 No. 3, pp. 314-324.

Holmberg, I. and Tyrstrup, M. (2010), "Well then - What now? An everyday approach to managerial leadership", Leadership, Vol. 6 No. 4, pp. 353-372.

Huse, M. (2005), “Accountability and creating accountability: A framework for exploring behavioural perspectives of corporate governance", British Journal of Management, Vol. 16, No. S1, pp. S65-S79.

Jarzabkowski, P., Balogun, J. and Seidl, D. (2007), "Strategizing: The challenges of a practice perspective", Human relations, Vol 60 No. 1, pp. 5-27.

Jensen, M.C. and Meckling, W.H. (1976), "Agency Costs and the Theory of the Firm", Journal of Financial Economics, Vol. 3 No. 4, pp. 305-360.

Kakabadse, A., Kakabadse, N.K. and Barratt, R. (2006), "Chairman and chief executive officer (CEO): that sacred and secret relationship", Journal of Management Development, Vol. 25 No. 2, pp. 134-150. 
Kakabadse, A.P., Kakabadse, N.K., and Knyght, R. (2010), "The chemistry factor in the Chairman/CEO relationship", European Management Journal, Vol. 28 No. 4, pp. 285296.

Kakabadse, A.P., Kakabadse, N.K. and Lee-Davies, L. (2007), "Three temptations of leaders", Leadership \& Organization Development Journal, Vol. 28 No. 3, pp. 196-208. Krippendorff, K. (2013), Content analysis: An introduction to its methodology, $3^{\text {rd }}$ edition, Sage, Thousand Oaks.

Kulla, J. (2011), "Käskyttämällä ei pitkälle pääse." Tutkimus suurten suomalaisyritysten toimitusjohtajien johtamiskokemuksista. ("By Dictating You Can't Get Far." A Study of the CEO Leadership Experiences in the Big Finnish Companies.) Doctoral dissertation, Department of Industrial Engineering and Management, Aalto University, Espoo.

Lindgren, M. and Packendorff, J. (2011), "Issues, responsibilities and identities: A distributed leadership perspective on biotechnology R\&D management", Creativity and Innovation Management, Vol. 20 No. 3, pp. 157-170.

Lindgren, M., Packendorff, J. and Tham, H. (2011), "Relational dysfunctionality: Leadership interactions in a Sarbanes-Oxley Act implementation project", European Journal of International Management, Vol. 5 No.1, pp. 13-29.

Pettigrew, A.M. (1992), “On studying managerial elites”, Strategic management journal, Vol. 13 (S2), pp. 163-182.

Pietiläinen, M., Keski-Petäjä, M. and Katainen, A. (2015), "Naisten ja miesten edustus yritysten ylimmässä johdossa." ("Male and Female Representation in Senior Corporate Management.") Publications of the Ministry of Social Affairs and Health, Helsinki.

Raelin, J. (2011), "From leadership-as-practice to leaderful practice", Leadership, Vol. 7, No. 2, pp. 195-211.

Roberts, J. (2002), "Building the complementary Board. The work of the plc chairman", Long Range Planning, Vol. 35 No. 5, pp. 493-520.

Roberts, J. and Stiles, P. (1999), "The Relationship between Chairmen and Chief Executives: Competitive or Complementary Roles?", Long Range Planning, Vol. 32 No. 1, pp. 36-48.

Stewart, R. (1991), "Chairmen and chief executives: An exploration of their relationship", Journal of Management Studies, Vol. 28, No. 5, pp. 511-528. 
Tourish, D. and Barge, J.K. (2010), "An exchange of letters: what can a specifically social constructionist perspective bring to bear on what must be one of the most studied subjects in human history?", Management Communication Quarterly, Vol. 24 No. 2, pp. 322-347.

Uhl-Bien, M. (2006), "Relational leadership theory: Exploring the social processes of leadership and organizing", The Leadership Quarterly, Vol. 17 No. 6, pp. 654-676.

Uhl-Bien, M. and Ospina, S.M. (2012), "Paradigm interplay in Relational Leadership", in Uhl-Bien, M. and Ospina, S.M. (Eds.), Advancing relational leadership research: a dialogue among perspectives, Information Age Publishing, Charlotte, NC, pp. 537-580. Whittington, R. (1996), "Strategy as practice", Long range planning, Vol. 29 No. 5, pp. 731-735.

Wood, M. (2005), "The Fallacy of Misplaced Leadership*”, Journal of Management Studies, Vol. 42. No. 6, pp. 1101-1121.

Yukl, G. (2006), Leadership in organizations (6th ed.), Prentice Hall, Upper Saddle River.

Zahra, S.A. and Pearce, J.A. (1989), "Boards of directors and corporate financial performance: A review and integrative model", Journal of Management, Vol. 15 No. 2, pp. 291-334.

Zhang, P. (2013), "Power and trust in Board-CEO relationships", Journal of Management \& Governance, Vol. 17 No. 3, pp. 745-765. 